\title{
Six Sigma Practices and Organizational Performance in Malaysian Healthcare Industry
}

\author{
Nur Afni Khaidir ${ }^{1}$, Nurul Fadly Habidin ${ }^{2}$, Naimah Ali ${ }^{1}$, Nurul Aifaa Shazali ${ }^{1}$, \\ Noor Hidayah Jamaludin ${ }^{1}$ \\ ${ }^{1}$ (Department of Accounting and Finance, Universiti Pendidikan Sultan Idris, Perak, Malaysia) \\ ${ }^{2}$ (Department of Management and Leadership, Universiti Pendidikan Sultan Idris, Perak, Malaysia)
}

\begin{abstract}
Successful of six sigma (SS) implementation have been reported in manufacturing industries. Recently, SS practices as quality management initiatives received the wide attention of many practitioners and researchers in service industry such as healthcare industry. The purpose of this study is to review structural analysis the SS and organizational performance $(O P)$ in Malaysian healthcare industry. SS is matched with healthcare sector because the healthcare nature of zero tolerance for medical error. A conceptual model using Structural Equation Modeling (SEM) has been proposed and will be used to study the relationship between SS practices and OP. Based on the previous study and proposed research model, research hypotheses are being developed.
\end{abstract}

Keywords: Six Sigma Practices, quality management initiative, organizational performance, healthcare and Malaysia

\section{INTRODUCTION}

Recently, healthcare industry is expending well within the public and private sector. Confirming to that, one of the largest private group in Malaysia, KPJ Healthcare Berhad which earned a profit after tax increased from year to year. It shows in year 2007 until 2011, their profit are RM77.8 million, RM89.3 million, RM114.7 million, RM126.2 million and RM154.3 million respectively [1]. This increment the healthcare industry is expending rapidly. In addition, the communities are very concerned about healthcare and expected good service when obtaining services. In line with the request, the healthcare industry should take initiative to improve their services in order to satisfy customer's needs [2] and reducing operating cost [3].

On top of that, reduce medical error, improving worker productivity and patient safety have become impressing issue in healthcare industry to enhance their organizational performance (OP). Therefore, to meet OP, healthcare industry can use and apply many quality management initiatives such as Six Sigma (SS), Total Quality Management (TQM), Lean Production (LP), Balanced Scorecard (BSC) and others [4]. The main objective of this paper is to review structural analysis the SS and OP in Malaysian healthcare industry. Hence, there are four indicators of SS which are leadership; customer focus; structured improvement procedure; and focus in metric. For dependent variables (OP), there are four indicators which is financial performance; customer performance; internal business process performance; and innovation and learning growth performance.

Next, this paper is organized as follow: in section 2, the literature of study consisting SS practices, OP and healthcare industry are reviewed; in section 3, research methodology are described; in section 4, proposed research model are presented; and finally in section 5, conclusion and future research are discussed.

\subsection{Six Sigma Practices}

\section{Literature Review}

Motorola is the pioneer and first company that using SS method at 1980's. Their engineer, Bill Smith came up with idea of this method to improve their quality management of product. Statistically, the aiming of SS is to reduce defect rate of 3.4 defects per one million of opportunities (DPMO) or almost free-error $[5 ; 6 ; 7 ; 8]$ SS in business viewpoint focus more to meet expectation and enhancing customer satisfaction $[9 ; 10]$ by improving the effectiveness and efficiency of all operation [11]. Various definitions of SS had stated among previous researchers with reflect different perspective. Table 1 shown the summary of definition of SS.

Table 1: The summary of definition of six sigma

\begin{tabular}{|l|l|}
\hline \multicolumn{1}{|c|}{ Authors } & \multicolumn{1}{c|}{ Definition } \\
\hline Habidin [4] & $\begin{array}{l}\text { SS having a great effect to increase quality by minimize defect rate and maximize the } \\
\text { performance and capability }\end{array}$ \\
\hline $\begin{array}{l}\text { Llyod and } \\
\text { Holsenback [7] }\end{array}$ & $\begin{array}{l}\text { The aims of SS are to reduce and eliminate waste, enhance customer satisfaction and } \\
\text { increase the profitability }\end{array}$ \\
\hline Thomas et al. [9] & SS goal is to reducing manufacturing and service cost \\
\hline
\end{tabular}




\begin{tabular}{|l|l|}
\hline Brun [10] & $\begin{array}{l}\text { Implementing SS in organization is focus to increase customer satisfaction by improved } \\
\text { processes capability. }\end{array}$ \\
\hline Gilbert [12] & $\begin{array}{l}\text { SS is a tool which is data driven, process improvement, identify the problem to achieve } \\
\text { bottom line results }\end{array}$ \\
\hline Heuvel et al. $[13]$ & $\begin{array}{l}\text { SS is not just trick to organize improvement projects but it is a set of managerial } \\
\text { instruments to achieve the results of improvement projects and maximising the } \\
\text { performance. }\end{array}$ \\
\hline $\begin{array}{l}\text { Kwak and Anbari } \\
{[14]}\end{array}$ & $\begin{array}{l}\text { SS is a business strategy that focuses on meet the expectation of customer needs, business } \\
\text { system, productivity and financial returns with reducing the cost. }\end{array}$ \\
\hline $\begin{array}{l}\text { Buyukozkan and } \\
\text { Ozturkcan [15] }\end{array}$ & $\begin{array}{l}\text { SS is a company-wide systematic approach to achieving continuous process } \\
\text { improvements }\end{array}$ \\
\hline
\end{tabular}

An organization defines as world class organization if they apply SS in every process [16]. SS as quality management program has been well recognized and it has been implemented by many world class organizations. Besides, SS also have been known as initiatives that are important to operation and business excellence [17]. In the manufacturing industry, world class transnational organization such as Motorola, General Electric, Sony [17], Samsung, Hyundai [18], and so on also had got the great successful by obtained millions of dollars in savings, increased customer satisfaction [17], obtained high level results, improved their work processes, enhancing employees' skills and change the culture [19]. In the service industry, the large companies such as American Express, City Bank, Zurich Financial Services [17], Korea Telecom [18], City Group [20] and others has been successful and get the benefit from SS quality management program.

Recently, operation management research are concerning SS in various sector are rapidly growing. Table 2 shows some examples of research SS base on sectors.

Table 2: Research of six sigma base on sectors

\begin{tabular}{|l|l|}
\hline \multicolumn{1}{|c|}{ Sectors } & \multicolumn{1}{c|}{ Authors } \\
\hline Healthcare and hospitality & $\begin{array}{l}\text { Lifvergren } \text { et al. [2]; Thomerson [3]; Antony [17]; Antony [21]; } \\
\text { Behnke and Breyfogle [22]; Antony } \text { et al. [23];; Aboelmaged [24] }\end{array}$ \\
\hline Financial & $\begin{array}{l}\text { Antony [17]; Antony [21]; Behnke and Breyfogle [22]; Aboelmaged } \\
\text { [24]; Heckl } \text { et al. [25]; Chen } \text { et al. [26] }\end{array}$ \\
\hline Education and training & Kim [27]; Saludin and Tan [28]; Mehrabi [29] \\
\hline Automotive & Habidin [4]; Abreu et al. [30] \\
\hline Military & Thompsen [31] \\
\hline $\begin{array}{l}\text { Software and information technology } \\
\text { (IT) }\end{array}$ & Aboelmaged [24]; Hong and Goh [32] \\
\hline
\end{tabular}

$\mathrm{Zu}$ et al. [33] identified the critical associated with SS practices which are role structure, structured improvement procedure and focus in metric. While Schroeder et al. [34] defined SS in four relevant elements which are parallel-meso structure, improvement specialists, structured method, and performance metrics. Snee and Hoerl [35] also discovered the key of successful factors in SS such as committed leadership, use of top talent in SS roles, and an appropriate support infrastructure while Kwak and Anbari [14] stated that management involvement and organizational commitment; project selection, management, and control skills; encouraging and accepting cultural change; and continuous education and training as key of successful factors in SS. This study is concerning SS in leadership, customer focus, structured improvement procedure and focus in metric.

\subsubsection{Leadership}

Leadership is critical for SS to success [34]. A leader needs to have a powerful influenced and respected from organization [36]. When leader have characteristic with full commitment, so it make easy to implement SS in organization because leader can organize and synergize employee's activities [36] and ensure every employees participate in every project [37] to achieve the organization's goals. In addition, leader should improve in decision making appropriately, timely, effectively, and efficiently that will make organization get the chance to increased product or service performance and enhance the profitability [38].

\subsubsection{Costumer focus}

Another critical success factors to ensure long term organizational survival and achieve organization goal is to understand and incorporate customer needs and expectation [37;39;40]. Based on Deming [41], to design a product or service, organization should stress the customer's present and future needs. Costumer will demand better quality products or services continuously, and to fulfil their expectation, organization has to use various approaches [8]. In relation to that, SS is one of the well-known approaches that can use to meet customer needs. This is because customer focus plays an important role to achieve continuous quality improvements [42] customer satisfaction and value [43]. Cheng [20] also state that SS emphasize base on the 
voice of customer. Hence, every suggestion, requirement or information from customer will consider [44] and it will become key competitors in searching for business excellence [20].

\subsubsection{Structured improvement procedure}

Basically, improvement is part of our culture [45] and it is driven better performance. Schroeder $e t$ al. [34] noted that structure method refers to the theory of organizational routines which is changing the organization's routines to established routines or implement new routine meanwhile, Sodikoglu and Zehir [36] stated that continuous improvements is searching for never ending improvements until find the suitable and better methods. $\mathrm{Zu}$ et al. [33] described structured improvement procedure as standardized procedure in planning and conducting improvement project. SS had well known the best approach to process improvement [35]. Besides that, SS allow a way of improving process that assists organization to produce world class products and services [9]. Coinciding with this, Jenicke et al. [8] stipulated that companies in US and other part of world had been successfully implemented SS to improve better quality of products or services. However, recently, Lifvergren et al. [2] also recommended implement SS as improvement practices in healthcare development initiatives.

\subsubsection{Focus in metrics}

Most of organizations have dilemma in identifying what to measure [46]. Organization should have a clear idea, selecting and measuring the correct metrics [47;48;49]. SS metrics are used to set improvements goals $[33 ; 50]$. When the organization set their measurement system, they have to track and follow up the progress of the project and result [35;37;51]. Most of the employee in organization must understanding of work processes to achieve the organization's goal [52;53]. Schroeder et al. [34] discovered that in manufacturing and service organization used a variety of special metrics such as process sigma measurements, critical to quality metrics, financial measures, and strategic measures.

SS proved had been implemented successfully whether in manufacturing and service industry. Recently, Swink and Jacobs [54] investigated the operational impacts of SS programs adoptions and the authors discover that SS adoption have a significant positive effect on profitability and sales growth. Others research findings on SS study shown in Table 3.

Table 3: The summary of research findings on six sigma study

\begin{tabular}{|l|l|}
\hline \multicolumn{1}{|c|}{ Authors } & \multicolumn{1}{c|}{ Findings } \\
\hline Zu et al. [33] & $\begin{array}{l}\text { The study discovers SS practices assist to enhance performance improvement in United } \\
\text { States manufacturing industry. }\end{array}$ \\
\hline $\begin{array}{l}\text { Habidin and Yusof } \\
\text { [52] }\end{array}$ & $\begin{array}{l}\text { Authors found that there is positive and direct strong relationship between SS (structured } \\
\text { improvement procedures and focus in metric) and financial performance in Malaysian } \\
\text { automotive industry. }\end{array}$ \\
\hline $\begin{array}{l}\text { Kumar and Kwong } \\
\text { [55] }\end{array}$ & $\begin{array}{l}\text { Using SS on operations of retail pharmacy is very applicable and quiet effective in helping } \\
\text { to streamline and integrate the pharmacy process flow }\end{array}$ \\
\hline
\end{tabular}

\subsection{Organizational Performance}

Typically, achievement of adopted quality management initiatives, organizations want to measure the performance of their goals. Coinciding with this, researches investigate various types of performances such as business performance, firm performance, quality performance, innovation performance, financial performance, organizational performance, customer satisfaction and so on. Macinati [56] noted that OP can be measured in multi-dimensional approach. Table 4 shown the measurement of OP that had been carried out by previous researchers. Authors proposed OP in four ways which are financial performance, customer performance, internal business process performance and innovation and learning growth performance.

Table 4: Measurement of organizational performance

\begin{tabular}{|l|l|}
\hline \multicolumn{1}{|c|}{ Authors } & \multicolumn{1}{c|}{ Measurement of organizational performance } \\
\hline Habidin [4] & $\begin{array}{l}\text { Financial performance; customer performance; internal business process; } \\
\text { innovation and learning growth }\end{array}$ \\
\hline Macinati [56] & Financial performance; operational performance; outcome performance \\
\hline Terziovski and Samson [57] & $\begin{array}{l}\text { Bussiness performance; operational performance; employee relations; customer } \\
\text { satisfaction }\end{array}$ \\
\hline Fotopoulos and Psomas [58] & $\begin{array}{l}\text { Internal procedures; customers; market share; the natural and social } \\
\text { environment. }\end{array}$ \\
\hline Keramati et al. [59] & Customer satisfaction; Economic performance \\
\hline
\end{tabular}




\subsubsection{Financial performance}

Financial performance is a tangible outcome in every organization [60]. Other than that, it shows the organization's financial status [61]. Financial performance measures in financial terms such as revenue, debt, cash flow, profit, and many others. Table 5 shown financial measurement items suggested in literature.

Table 5: Financial measurement items suggested in literature

\begin{tabular}{|l|c|c|c|c|c|c|c|c|}
\hline & A & B & C & D & E & F & G & $\square$ \\
\hline $\begin{array}{l}\text { Increased operating } \\
\text { revenues }\end{array}$ & $*$ & $*$ & $*$ & $*$ & $*$ & $*$ & $*$ & 6 \\
\hline Reduced costs & & & & $*$ & $*$ & $*$ & $*$ & 4 \\
\hline Decreased debt & $*$ & & $*$ & & & $*$ & $*$ & 4 \\
\hline Increased cash flow & $*$ & & $*$ & & & $*$ & & 3 \\
\hline Increase profit & & & $*$ & $*$ & $*$ & & $*$ & 4 \\
\hline
\end{tabular}

(A) Karra and Papadopoulos [62]; (B) Urrutia and Eriksen [63]; (C) Revere et al. [61]; (D) Gurd and Gao [64]; (E) Macinati [56]; (F) Habidin, [4]; (G) Grigoroudis et al. [60]

\subsubsection{Customer performance}

Antony et al. [23] discovered that SS practices can improve customer performance in healthcare industry. Habidin [4] interpreted understanding need, information and data from customers will give benefits to organization to produce high quality product or service, improving productivity and increase the profitability. Customer performance can measure in a many ways like customer satisfaction, customer loyalty, customer request, and so on. Table 6 presented customer measurement items suggested in literature.

Table 6: Customer measurement items suggested in literature

\begin{tabular}{|l|c|c|c|c|c|c|}
\hline & A & B & C & D & E & $\square$ \\
\hline $\begin{array}{l}\text { Increased customer } \\
\text { satisfaction }\end{array}$ & $*$ & $*$ & $*$ & $*$ & $*$ & 5 \\
\hline $\begin{array}{l}\text { Improve respond to } \\
\text { customer complaints }\end{array}$ & & $*$ & $*$ & $*$ & & 2 \\
\hline Increased acquisition & & $*$ & $*$ & $*$ & & 3 \\
\hline $\begin{array}{l}\text { Increased customer } \\
\text { retention }\end{array}$ & & & $*$ & & 1 \\
\hline $\begin{array}{l}\text { Improve respond to } \\
\text { customer request }\end{array}$ & & & & $*$ & 3 \\
\hline
\end{tabular}

(A) Urrutia and Eriksen [63]; (B) Revere et al. [61]; (C) Gurd and Gao [64]; (D) Habidin [4]; (E) Grigoroudis et al. [60]

\subsubsection{Internal business process performance}

Many organizations focus in internal business process like product or service quality, management efficiency, enhance operation and so on. Effectiveness and efficiency of internal business process give the greatest impact to customer and achieve the financial goals [60;61]. Table 7 shown internal business process performance measurement items suggested in literature.

Table 7: Internal business process measurement items suggested in literature

\begin{tabular}{|l|c|c|c|c|c|c|c|c|}
\hline & A & B & C & D & E & F & G & $\square$ \\
\hline $\begin{array}{l}\text { Improvement of internal } \\
\text { process efficiency }\end{array}$ & & $*$ & $*$ & $*$ & $*$ & $*$ & $*$ & 6 \\
\hline $\begin{array}{l}\text { Improvement of } \\
\text { management efficiency }\end{array}$ & & & $*$ & $*$ & $*$ & & $*$ & 4 \\
\hline $\begin{array}{l}\text { Improvement of product/ } \\
\text { service quality }\end{array}$ & & & $*$ & & & $*$ & & 2 \\
\hline $\begin{array}{l}\text { Improvement strategic } \\
\text { forecasting }\end{array}$ & & & & & & $*$ & $*$ & 2 \\
\hline Reduced the defect & $*$ & & & & & & $*$ & 2 \\
\hline
\end{tabular}

(A) Fuentes-Fuentes et al. [65]; (B) Karra and Papadopoulos [62]; (C) Urrutia and Eriksen [63]; (D) Elbashir et al. [66]; (E)Wu [67]; (F) Rajesh et al. [68]; (G) Habidin [4]

\subsubsection{Innovation and learning growth performance}

Innovation and learning growth performance focus on the ability of employees, the quality of information systems, and the effects of organisational alignment to achieve organization's goals [69]. Table 8 presented the innovation and learning growth performance measurement items suggested in literature. 
Table 8: Innovation and learning growth measurement items suggested in literature

\begin{tabular}{|l|c|c|c|c|c|c|c|c|c|}
\hline & A & B & C & D & E & F & G & H & $\square$ \\
\hline $\begin{array}{l}\text { Increased employee } \\
\text { satisfaction }\end{array}$ & $*$ & $*$ & $*$ & & $*$ & & $*$ & $*$ & 6 \\
\hline $\begin{array}{l}\text { Improved employee } \\
\text { training/ learning }\end{array}$ & & $*$ & $*$ & $*$ & $*$ & $*$ & $*$ & & 6 \\
\hline $\begin{array}{l}\text { Improved continuous } \\
\text { improvement }\end{array}$ & & & $*$ & $*$ & & & & & 2 \\
\hline $\begin{array}{l}\text { Improved technology } \\
\text { development }\end{array}$ & & & & & $*$ & $*$ & $*$ & 3 \\
\hline $\begin{array}{l}\text { Improved the new product/ } \\
\text { service }\end{array}$ & & & $*$ & & $*$ & & $*$ & & 3 \\
\hline $\begin{array}{l}\text { Improved the innovation } \\
\text { development }\end{array}$ & & & $*$ & $*$ & & & & & 2 \\
\hline
\end{tabular}

(A) Fuentes-Fuentes et al. [65]; (B) Urrutia and Eriksen [63]; (C) Gurd and Gao [64]; (D) Guimaraes et al. [70]; (E) Wu [67]; (F) Rajesh et al. [68]; (G) Habidin [4]; (H) Grigoroudis et al. [60]

There are many previous study investigated quality management with OP. Table 9 presented the summary of research findings on OP.

Table 9: The summary of research findings on organizational performance

\begin{tabular}{|l|l|}
\hline \multicolumn{1}{|c|}{ Authors } & \multicolumn{1}{|c|}{ Findings } \\
\hline $\begin{array}{l}\text { Fotopoulos and } \\
\text { Psomas [58] }\end{array}$ & $\begin{array}{l}\text { The objective of the study is to investigate the relationships between the TQM factors and } \\
\text { organizational performance. Authors identified that TQM affect the organizational } \\
\text { performance. }\end{array}$ \\
\hline $\begin{array}{l}\text { Fuentes-Fuentes } \text { et al. } \\
\text { [65] }\end{array}$ & $\begin{array}{l}\text { This study investigated the relationship between total quality management and } \\
\text { organizational performance of Spanish firms. This study found customer focus (TQM) has a } \\
\text { positive affect to financial and operational performance (organizational performance) }\end{array}$ \\
\hline Elbashir et al. [66] & $\begin{array}{l}\text { This study discovers there are a positive and significant relation between business process } \\
\text { (customer intelligence; supplier relations; internal efficiency) and organization } \\
\text { performance. }\end{array}$ \\
\hline Akgun et al. $[$ [71] & $\begin{array}{l}\text { Authors found that there are positive relationship between firm innovativeness and } \\
\text { organizational (firm) performance in Turkish firms. }\end{array}$ \\
\hline Lee et al. [72] & $\begin{array}{l}\text { The purpose of the study is to investigate relationship between quality management } \\
\text { practices and organizational performances in Korean healthcare industry. They found } \\
\text { quality management practices have the significant impact to organizational performances. }\end{array}$ \\
\hline
\end{tabular}

\subsection{Healthcare Industry}

Recently, the implementations of SS practices not only focus to manufacturing industry, but also in service industry. For example, Lifvergren et al. [2] noted that SS is practical concept in enhancing healthcare processes. In regards to that, Ministry of Health Malaysia has adopted SS methodology to improve their quality services [73]. Besides that, the SS is matched with healthcare sector because the healthcare nature of zero tolerance for medical error in the processes [14;74]. Stock et al. [75] defined two types of medical error which is human error and non-human error. SS can be applied to almost of healthcare organization such as radiology, nursing, pharmacy and so on as shown in Table 10.

Table 10: Research of six sigma in healthcare by sectors

\begin{tabular}{|l|l|}
\hline \multicolumn{1}{|c|}{ Sectors } & \multicolumn{1}{c|}{ Authors } \\
\hline Radiology & $\begin{array}{l}\text { Thomerson [3]; Llyod and Holsenback [7]; Cherry and Seshadri [76]; } \\
\text { Bahensky } \text { et al. [77]; }\end{array}$ \\
\hline Nursing & Heuvel et al. [13]; Simmons et al. [78] \\
\hline Medication & Lifvergren et al. [2]; Revere and Black [79] \\
\hline Surgery & Lifvergren et al. [2] \\
\hline
\end{tabular}

The succeed in adopted SS in healthcare industry can be seen in the study of Lifvergren et al. [2] discover that $75 \%$ which is 15 out of 22 projects that have been implemented using the SS practices in Skaraborg Hospital Group (SKaS), Sweden for a period of 3 years (2006-2008) reached their intended goals. Besides, the net cost savings per completed project/year amounts to US\$55,300. Table 11 presents the summary of research findings on SS in healthcare industry. 


\subsection{Six Sigma Practices and Organizational Performance}

The investigation between SS practices and performance has received substantial attention. Habidin [4] found lean SS implementation has a direct and strong relationship on OP in Malaysian automotive industry. Abreu et al. [30] discovered SS can be used in organization to handling customer complaints. In addition, Swink and Jacobs [54] found overall effects of SS adoption are typically positive to financial performance in service firms. Like manufacturing industries that have successfully implemented SS, service industry like healthcare also can get the benefits from implementing SS [17]. According to Antony et al. [23], implementing SS had improved the financial, operational and customer performance of United Kingdom National Health Service.

On top of that, Thomerson [3] discovered Commonwealth Health Corporation (CHC) excess \$1.2 million, increased radiology throughput of $33 \%$ and savings of $21.5 \%$ per radiology procedure when implemented SS. Heuvel et al. [80] also identified the result of implementing SS practices at the Red Cross Hospital in Beverwijk, Netherlands towards financial performance that shows the completed projects produced $€ 1.2$ million in annual savings. In addition, Hilton et al. [74] carried out the critical success factor at SS initiatives (training; close customer relationships; process improvement; measurement; organizational structures; and zero defect mentality) for Australian hospital are significantly positive correlated to performance (equitable and timely access into the clinical services of emergency, outpatients and surgery; the appropriate safe and timely discharge back to the community) at $1 \%$. To understand the relationship between SS practices and OP in Malaysia healthcare industry, the following propose hypothesis will be test.

$\boldsymbol{H}_{1}$ : There is a positive and direct significant relationship between six sigma practices implementation and organizational performance in Malaysian healthcare industry

\section{Research Methodology}

Healthcare industries were chosen because the use of quality initiative and performance measurement in this sector is very important. It is an important industrial driver of industrial management and development, because it brings together various components, which are manufactured by suppliers in other industries [81]. In this study, samples were selected from the list of hospital in Malaysian. In achieving the objectives of the study, the Malaysian private hospitals were selected as the population. Authors will use the structured questionnaire as sampling method.

Structural Equation Modeling (SEM) techniques was utilize to perform the require statistical analysis of the data from the survey. Exploratory factor analysis, reliability analysis and confirmatory factor analysis to test for construct validity, reliability, and measurements loading were performed. Having analysed the measurement model, the structural model was then tested and confirmed. The statistical Package for the Social Sciences (SPSS) version 17 was used to analyze the preliminary data and provide descriptive analyses about thesis sample such as means, standard deviations, and frequencies. SEM using AMOS 6.0 will use to test the measurement model.

\section{Proposed Research Model}

Based on literature review before, there are many previous study investigating SS practices and OP. Authors propose to analyze the relationship between SS and OP in Malaysian healthcare industry. Figure 1 presented the proposed research model.

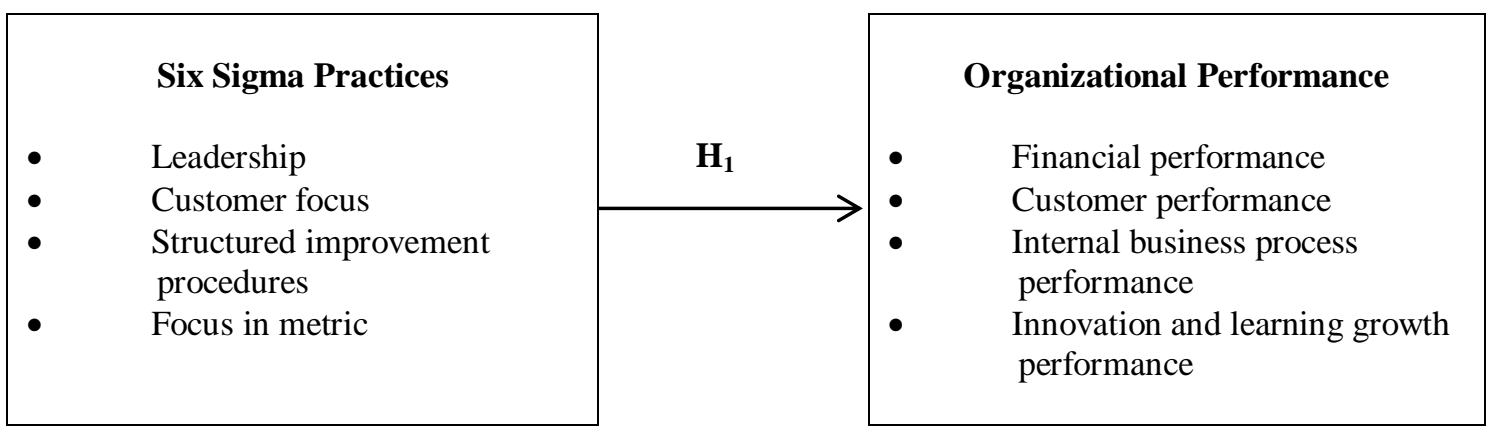

Figure 1:

Proposed model of the study 


\section{Conclusion and Future Research}

SS practices are quality management initiatives that get the wide attention of many practitioners and researchers. The positive relationship between SS practices and many OP had been proved with previous study [82]. In order to that, the purpose of this study is to carry out structural analysis the SS practices (leadership; costumer focus; structured improvement procedure and; focus in metric) and OP (financial performance; customer performance; internal business process performance and; innovation and growth learning performance) in Malaysian healthcare industry. This study also has conducted based on the proposed conceptual model. From previous study and proposed research model, research hypothesis are being develop. Future agenda, in order to get the empirical result, set of questionnaire are develop and analyse according to SEM techniques.

\section{Acknowledgement}

The researchers would like to acknowledge the Ministry of Higher Education (MOHE) for the financial funding of this research thought Fundamental Research Grant Scheme (FRGS), Research Management Centre (RMC), Universiti Pendidikan Sultan Idris (UPSI) for Research University Grant (RUG).

\section{References}

[1] Annual Report KPJ Healthcare Berhad, 2011, [Website] URL: http://www.bursamalaysia.com/market/listed-companies/companyannouncements/972669, [Accessed on $20^{\text {th }}$ October 2012]

[2] Lifvergren, S., Gremyr, I., Hellstrom, A., Chakhunashvili, A., Bergman, B. Lessons from Sweden's first large-scale implementation of Six Sigma in healthcare. Operations Managment Research, 3, 2010, 117-128.

[3] Thomerson, L. D. Journey for excellence: Kentucky's Commonwealth Health Corporation adopts Six Sigma approach. Quality Congress. ASQ's Annual Quality Congress Proceedings, 2001, 152-158.

[4] Habidin, N. F. The structural analysis and development tool of Lean Six Sigma, strategic control system and organizational performance in Malaysian Automotive Industry, Engineering Doctorate Thesis, Faculty of Engineering , University Technology Malaysia, Malaysia, 2012.

[5] Pande P. S., Neuman, R. P., and Cavanagh, R.R. (2000). The six sigma way: How GE, Motorola, and other top companies are honing their performance (New York: McGraw-Hill, 2000).

[6] Pandey, A. Strategically focused training in six sigma way: A case study. Journal of European Industrial Training, 31(2), 2007, $145-162$.

[7] Llyod, D. H., and Holsenback, J. E. The use of six sigma in health care operations: Application and opportunity. Academy of Health Care Management Journal, 2, 2006, 41-49.

[8] Jenicke, L. O., Kumar, A., and Holmes, M. C. A framework for applying six sigma improvement methodology in an academic environment. The TQM Journal, 20(5), 2008, 453-462

[9] Thomas, A., Barton, R., and Chuke-Okafor, C. Applying lean six sigma in a small engineering company - a model for change. Journal of manufacturing Technology Management, 20(1), 2009, 113-129

[10] Brun, A. Critical success factors of Six Sigma implementations in Italian companies. International Journal of Production Economics, 131, 2010, 158-164

[11] Fuller, B., and Clarke, P. Raising school effects while ignoring culture: Local conditions and the influence of classroom tools, rules and pedagogy. Review of Educational Research ,64 (1), 1994, 119157.

[12] Gilbert, E. R. Integrating accelerated problem solving into the six sigma process improvement methodology. Thesis of North Crolina State University, USA, 2003

[13] Heuvel, J. V. D., Does, R. J. M. M., and Bisgaard, S. Why implementing six sigma in a hospital? Six Sigma Forum Magazine, 4(2), 2004, 11-14.

[14] Kwak, Y. H., and Anbari, F. T. Benefits, obstacles, and future of six sigma approach. Technovation, 26, 2006, 708-715.

[15] Buyukozkan, G., and Ozturkcan, D. An integrated analytic approach for Six Sigma project selection. Experts Systems with Application, 37, 2010, 5835-5847.

[16] Harry, M. Six Sigma-A breakthrough strategy for profitability. Quality Progress, 31(5), 1998, 60-63.

[17] Antony, J. Six sigma for services processes. Business Process Management Journal, 12(2), 2006, 234 - 248

[18] Cho. J. H., Lee, J. H., Ahn, D. G., and Jang J. S. Selection of Six Sigma key ingredients (KIs) in Korean companies. The TQM Journal, 23(6), 2011, 611-628.

[19] Aboelmaged, M. G. Six Sigma quality: A structured review and implications for future research. International Journal of Quality \& Reliability Management, 27(3), 2010, 268 - 317.

[20] Cheng, J. L. Comparative study of local and transnational enterprises in Taiwan and their implementation of six sigma. Total Quality Management, 18(7), 2007, 793-806.

[21] Antony, J. Six Sigma in the UK service organisations: results from a pilot survey. Managerial Auditing Journal, 19(8), 2004, 10061013.

[22] Behnke, L., and Breyfogle, F. Focusing the power of six sigma in the healthcare insurance industry: Lowering medical costs while improving patient service and outcomes. ASQ World Conference on Quality and Improvement Proceedings, 59, 2005, 449-455.

[23] Antony, J., Downey-Ennis, K., Antony, F., and Seow C. Can Six Sigma be the "cure" for our "ailing" NHS?. Leadership in Health Services, 20(4), 2007, $242-253$.

[24] Aboelmaged, M. G. Reconstructing Six Sigma barriers in manufacturing and service organizations: The effects of organizational parameters. International Journal of Quality \& Reliability Management, 28(5), 2011, 519 - 541.

[25] Heckl, D., Moormann, J., and Rosemann, M.. Uptake and success factors of Six Sigma in the financial services industry. Business Process Management Journal, 16(3), 2010, 436 - 472.

[26] Chen, Y. C., Chen, S.C., Huang, M. Y., and Tsai, C. L. Application of six sigma DMAIC methodology to reduce financial risk: A study of credit card usage in Taiwan. International Journal of Management, 29(3), 2012, 166-176.

[27] Kim, D. S. Eliciting success factors of applying Six Sigma in an academic library: A case study. Performance Measurement and Metrics, 11(1), 2010, $25-38$. 
[28] Saludin, M. N., and Tan, P. K. The importance of customer satisfaction and customer complaint towards a better quality service using six sigma: An academic perspective. Jurnal Teknologi, 5, 2010, 107-126.

[29] Mehrabi, J. Application of six-sigma in educational quality management. Procedia - Social and Behavioral Sciences, 47, 2012, $1358-1362$.

[30] Abreu, P., Sousa, S., Member, IAENG, and Lopes, I. Using six sigma to improve complaints handling. Proceedings of the World Congress on Engineering 2012, July 4 - 6, London, U.K, 2012.

[31] Thompsen, J. A. Gaining greater benefit from lean six sigma and leadership initiatives within the military. IEEE International Engineering Management Conference, 2, 2005, 846-850.

[32] Hong, G. Y., and Goh, T. N. A comparison of Six-sigma and GQM approaches in software development. International Journal of Six Sigma and Competitive Advantages, 1(1), 2004, 65-75.

[33] Zu, X., Fredendall, L. D., and Douglas, T. J. The evolving theory of quality management: The role of Six Sigma. Journal of Operations Management, 26, 2008, 630-650.

[34] Schroeder, R. G., Linderman, K., Liedtke, C., and Choo, A. S. Six Sigma: Definition and underlying theory. Journal of Operations Management, 26, 2008, 536-554.

[35] Snee, R. D. \& Hoerl, R. W. Leading Six Sigma (Englewood Cliffs, NJ: Prentice-Hall, 2003)

[36] Sadikoglu, E., and Zehir, C. Investigating the effects of innovation and employee performance on the relationship between total quality management practices and firm performance: An empirical study of Turkish firms. International Journal of Production Economics, 127, 2010, 13-26.

[37] Ho, Y. C., Chang, O. C., and Wang, W. B. An empirical study of key success factors for Six Sigma Green Belt projects at an Asian MRO company. Journal of Air Transport Management, 14, 2008, 263-269.

[38] Friday-Stroud S. S., and Sutterfield, J. S. A conceptual framework for integrating six-sigma and strategic management methodologies to quantify decision making. The TQM Magazine, 19(6), 2007, $561-571$.

[39] Deming W.E. Out of crisis. MIT Press, Cambridge, MA, 1986.

[40] Dean, H.W., and Bowen, D.E. Management theory and total quality: improving research and practice through theory development. The Academy of Management Review, 19 (3), 1994, 392-418.

[41] Deming Prize Criteria. Japanese Union of Scientists and Engineers. Japan, 1994

[42] Sester, D. Motorola: A tradition of quality. Quality, 40(10), 2001, 31-34.

[43] Pande, P., and Holpp, L. (2002) What is Lean Six Sigma? (NY:McGraw-Hill, 2002)

[44] Trojniak, D. J. Ways to evaluate voice of the customer information for meaningful improvement. ASQ's Annual Quality Congress Proceedings, 57, 2003, 243-257.

[45] Snee, R. D. Six-Sigma: the evolution of 100 years of business improvement methodology. International Journal of Six Sigma and Competitive Advantage, 1(1), 2004, 4-20.

[46] Sehwail, L., and DeYong C. Six sigma in healthcare. International Journal of Health Care Quality Assurance, 16 (4), 2003 , i-v.

[47] Goh, T.N. A strategic assessment of six sigma. Quality \& Reliability Engineering International, 18(5), 2002, 403-410.

[48] Chakrabarty, A., and Tan, K. C. The current state of six sigma application in services. Managing Service Quality, 17(2), 2007,194 -208 .

[49] Abdolshah, M., and Yusuff, R.M. Fundamental elements for the successful performance of Six Sigma projects in service industries, Proceeding of $11^{\text {th }}$ QMOD Conferences, Quality Management and Organizational Development Attaining Sustainability from Organizational Excellence to Sustainable Excellence, $20^{\text {th }}-22^{\text {nd }}$ August, Helsingborg, Sweden, 2008.

[50] Linderman, K., Schroeder, R.G., Zaheer, S., and Choo, A.S. Six Sigma: A goal-theoretic perspective. Journal of Operations Management, 21, 2003, 193-203.

[51] Jiju, A., and Banuelas, R. Key ingredients for the effective implementation of Six Sigma program. Measuring Business Excellence, 6, 2002, 20-27.

[52] Habidin, N. F., and Yusof, S. M. Six sigma, strategic control systems and financial performance in Malaysian automotive industry. Journal of Contemporary Issues and Thought, 1, 2011, 187-204.

[53] Hensley, R. L., and Dobie, K. Assessing readiness for six sigma in a service setting. Managing Service Quality 15(1), 2005, 82-101.

[54] Swink, M., and Jacobs, B. W. Six Sigma adoption: Operating performance impacts and contextual drivers of success. Journal of Operations Management, 30, 2012, 437-453.

[55] Kumar, S., and Kwong, A. M. Six sigma tools in integrating internal operations of a retail pharmacy: A case study. Technology and Health Care, 19, 2011, 115-133.

[56] Macinati, M. S. The relationship between quality management systems and organizational performance in the Italian National Health Service. Health Policy, 85, 2008, 228-241.

[57] Terziovski, M., and Samson, D. The effect of company size on the relationship between TQM strategy and organisational performance. The TQM Magazine, 12(2), 2000, 144-148.

[58] Fotopoulos, C. V., and Psomas, E. L. The structural relationships between TQM factors and organizational performance. The TQM Journal, 22(5), 2010, 539-552.

[59] Keramati, A., Mehrabi, H., and Mojir, N. A process-oriented perspective on customer relationship management and organizational performance: An empirical investigation. Industrial Marketing Management, 39, 2010, 1170-1185

[60] Grigoroudis, E., Orfanoudaki, E., and Zopounidis, C. Strategic performance measurement in a healthcare organization: A multiple criteria approach based on balanced scorecard. Omega, 40, 2012, 104-119.

[61] Revere, L., Black, K., and Love, D. An empirical investigation into healthcare performance indicators and the implications for developing a balanced scorecard. Mora-Monge CA,Proceedings of the $38^{\text {th }}$ south west decision sciences institute, DSI, San Diego, 2007, 505-514.

[62] Karra, E. D., and Papadopoulos, D. L. Measuring performance of Theagenion Hospital of Thessaloniki, Greece through a balanced scorecard. An international Journal of Operational Research, 5(2), 2005, 289-304.

[63] Urrutia, I., and Eriksen, S. D. Application of the Balanced Scorecard in Spanish private health-care management. Measuring Business Excellence, 9(4), 2005, 16-26.

[64] Gurd, B., and Gao, T. Lives in the balance: an analysis of the balanced scorecard (BSC) in healthcare organizations. International Journal of Productivity and Performance Management, 57(1), 2007, 6-21.

[65] Fuentes-Fuentes, M. M., Albacete-Saez, C. A., Llorens_montes, F. J. The impact of environmental characteristics on TQM principles and organizational performance. Omega, 32, 2004, 425-442.

[66] Elbashir, M. Z., Collier, P. A., and Davern, M. J. Measuring the effects of business intelligence systems: The relationship between business process and organizational performance. International Journal of Accounting Information Systems, 9, 2008, 135-153. 
[67] Wu, H. Y. Constructing a strategy map for banking institutions with key performance indicators of the balanced scorecard. Evaluation and Program Planning, 35, 2012, 303-320.

[68] Rajesh, R., Pugazhendhi, S., Ganesh, K., Ducq, Y., and Koh, S. C. L. Generic balanced scorecard framework for third party logistics service provider. International Journal of Production Economics, 140, 2012, 269-282.

[69] McPhail, R., Herrington, C., and Guilding, C. Human resource managers' perceptions of the applications and merit of the balanced scorecard in hotels. International Journal of Hospitality Management, 27, 2008, 623-631.

[70] Guimaraes, B., Simoes, P., and Marques, R. C. Does performance evaluation help public managers? A Balanced Scorecard approach in urban waste services. Journal of Environmental Management, 91, 2010, 2632-2638.

[71] Akgun A. E., Keskin, H., and Byrne, J. Organizational emotional capability, product and process innovation, and firm performance: An empirical analysis. Journal of Engineering and Technology Management, 26, 2009, 103-130.

[72] Lee, S. M., Lee, D. H., and Schniederjans, M. J. Supply chain innovation and organizational performance in the healthcare industry. International Journal of Operations \& Production Management, 31(11), 2012, 1193 - 1214

[73] Annual Report Ministry of Health $\quad$ Malaysia, 2007 [Website] http://www.moh.gov.my/images/gallery/publications/md/ar/2007-2.pdf, [Accessed on 15 ${ }^{\text {th }}$ October 2012]

[74] Hilton, R., Balla, M., and Sohal, A. S. Factors critical to the success of a Six-Sigma quality program in an Australian hospital. Total Quality Management, 19(9), 2008, 887-902.

[75] Stock G. N., McFadden, K. L., and Gowen III, C. R. Organizational culture, critical success factors, and the reduction of hospital errors. International Journal of Production Economics, 106, 2007, 368-392.

[76] Cherry J, and Seshadri, S. Six sigma: Using statistics to reduce process variability and costs in radiology. Radiology Management, 2000, 42-45.

[77] Bahensky, J. A., Roe, J., and Bolton, R. Lean sigma-will it work for healthcare? Journal of Healthcare Information Management, 19(1), 2005, 39-44.

[78] Simmons, D., Cenek, P., Counterman, J., Hockenhury, D., and Litwiller Reducing VAP with 6 Sigma - use quality improvement methodologies to enhance core patient care process. Nursing Managament, 35(6), 2004, 41-45.

[79] Revere, L., and Black, K. Integrating six sigma with total quality management: A case example for measuring medication errors. Journal of Healthcare Management, 48 (6), 2003, 377-391.

[80] Heuvel, J. V. D., Does, R. J. M. M., and Verver, J.P.S. Six sigma in healthcare: lesson learned from a hospital. International Journal of Six Sigma and Competitive Advantage, 1(4), 2005, 380-388.

[81] Chin, H. K., and Saman, M, Z. M. Proposed analysis of performance measurement for a production system. Business Process Management Journal, 10(5), 2004, 570-583.

[82] Yusr M. M., Othman, A. R., and Mokhtar, S. S. M. Six Sigma and Innovation Performance: A Conceptual Framework Based on the Absorptive Capacity Theory Perspective. International Journal of Emerging Sciences, 1(3), 2011, 307-323. 